\title{
Chimpanzees, sorcery and contestation in a protected area in Guinea-Bissau
}

Article

Accepted Version

Sousa, J., Hill, C. and Ainslie, A. (2017) Chimpanzees, sorcery and contestation in a protected area in Guinea-Bissau. Social Anthropology, 25 (3). pp. 364-379. ISSN 1469-8676 doi: https://doi.org/10.1111/1469-8676.12418 Available at https://centaur.reading.ac.uk/69726/

It is advisable to refer to the publisher's version if you intend to cite from the work. See Guidance on citing.

To link to this article DOI: http://dx.doi.org/10.1111/1469-8676.12418

Publisher: Wiley

All outputs in CentAUR are protected by Intellectual Property Rights law, including copyright law. Copyright and IPR is retained by the creators or other copyright holders. Terms and conditions for use of this material are defined in the End User Agreement.

\section{www.reading.ac.uk/centaur}

\section{CentAUR}

Central Archive at the University of Reading

Reading's research outputs online 


\title{
Chimpanzees, sorcery and contestation in a protected area in
}

\section{Guinea-Bissau}

\author{
Joana Sousa ${ }^{1,2,3}$, Catherine M. Hill ${ }^{2}$, Andrew Ainslie ${ }^{4}$
}

\author{
${ }^{1}$ Anthropology Centre for Conservation, Environment \& Development, Oxford Brookes University, \\ Oxford, UK. \\ ${ }^{2}$ Department of Geography and the Environment, University of Geneva, Switzerland. \\ ${ }^{3}$ Departamento de Ciências Ambientais, Universidade Lusófona da Guiné, Guiné-Bissau. \\ ${ }^{4}$ International Development Research Group, School of Agriculture, Policy and Development, \\ University of Reading, Reading, RG6 6AR, United Kingdom.
}

\begin{abstract}
(100 words)
In Cantanhez National Park in Guinea-Bissau the construction of meaning made upon encounters with chimpanzees is associated with local social life. If a chimpanzee makes an unprovoked attack on a person, its actions are often understood as those of a sorcerer. Chimpanzees are involved in two parallel accusation discourses, one is played in intimate spheres of sociability where sorcerers harm their kin to benefit from secret alliances, and the other addresses a wider audience perceived to benefit from chimpanzees which are being protected at the expense of other humans. Both narratives represent local criticism against transgressions to calculations of redistribution and reciprocity.
\end{abstract}

Key-words: chimpanzees, sorcery, national park, nature conservation, reciprocity.

Word count of the main manuscript: 7995 


\section{Chimpanzees, sorcery and contestation in a protected area in}

\section{Guinea-Bissau}

\section{Introduction}

Conservation is by its very nature political. Since the Game Preservation conference held in London in 1900, there has been more than a century of formal nature conservation effort and enforcement in African contexts. In the process, a wide range of programmes based on different conservation paradigms have been followed by colonial and post-colonial states, international agencies, conservation experts and funding bodies. Under colonial regimes, conservation programmes often involved the eviction of local people (Schmidt-Soltau 2005) to serve the economic and conservation goals of colonial administrations (Neumann 2002). During the 1950s, on the brink of independence sweeping across colonial Africa, the establishment of international organisations (IUCN, WWF, AWF) would divert the responsibility for African environmental management from colonial control to global governance institutions (Neumann 2002). There were some attempts during the 1970s to reconcile the goals of development with those of conservation (Roe 2008), particularly after the Stockholm Conference held in 1972, and vigorous attempts were made to establish a more harmonious ('win-win') relationship between nature conservation and development during the 1980s and 1990s . Approaches like "community-based conservation" became widespread and the idea that conserved areas should be more inclusive of the needs of local people became part of conservationist discourse (Adams and Hulme 2001). Nevertheless, studies undertaken during the 2000s (Roe 2008) continued to describe privation, social injustice, impoverishment and expropriation of local peoples as consequences of conservation (Brockington and Igoe 2006) with the acknowledgement that typically the costs and benefits of nature conservation 
are not distributed proportionally among actors. Perspectives about how conservation should relate to and be responsible for the mitigation of poverty remained contested (Adams et al 2004).

In the West African state of Guinea-Bissau, the peninsula of Cubucaré, in the extreme southwest of the country, was a latecomer to the internationally-supported goals of establishing protected areas. When Cubucaré was gazetted as Cantanhez National Park in 2008, decades of debate about conservation and development had already taken place in the literature. Nevertheless, several issues that engage critically with nature conservation discourses and practices remained to be examined and debated on the ground in this instance, particularly those concerning the sharing of benefits and the impositions attached to conservation initiatives. Significantly, with the establishment of the Cantanhez National Park, the region became immersed in an entanglement of two cosmological and ontologically different versions of the human and non-human world — that of 'nature' and that of 'matu'. Nature conservation represented Cantanhez as an isolated forested area marked by the northernmost remnants of sub-humid forests on the continent and home to biodiversity of global importance, including chimpanzees, which became the emblematic species of the park. However, in Cubucaré the idea of 'nature' or of 'biodiversity' finds no equivalent in Guinean Kriol (kl), the country's lingua franca, and the closest approximation to the term 'nature' is the term 'bush' (matu, kl). Indeed, within Guinean popular culture Cubucaré is commonly portrayed as isolated, backward and an extreme example of 'bush'. The term matu is used as a relative measure to define an isolated and vegetation-covered space such as a forest, an agricultural field or a fallow and therefore including humans and domesticated places. The social aspects of the 'bush' are regarded as conservative, healing, and occult-centred. 'Being of/from the bush' (djintis di matu, kl) indicates a commitment to this cosmological order. 
Thus, local cosmological views and conservation discourse are strikingly different regarding the range of possible relationships between people and between human and non-human.

The misunderstandings and asymmetries arising from protected areas in the global south can be analysed along at least two lines. First, conservation programmes are implemented in contexts of social differentiation where local farmers are considerably poorer and have less power than the conservation experts who impose limitations on local livelihoods (Grandia 2012). Biodiversity conservation programmes are conceived in a global arena where conservation initiatives comply with the norms and expectations of a market logic. When market economy-based governance collides with other modes of governance at the local level there are few mechanisms to deal with the asymmetric division of costs and benefits reproduced by conservation programmes. Second, recent literature on the ontological turn in anthropology has discussed the different ways nature is experienced and the ways of being with nature that are considered possible by different social groups (see Descola 2012). Cosmological views about the non-human world and human/non-human modes of relationality constitute specific ways of being with nature. However, the idea that there is not only one nature but multiple natures poses a serious problem, i.e. which 'nature' should be conserved and why?

In this paper we examine the linkages between the globalised discourse and practice of nature conservation and local cosmological views about people-animal interactions where nature conservation is integrated into critical, local assertions of grievance (including expropriation). In the narratives presented here the encounter between human and nonhumans is the place where the globally dominant versions of nature conservation are forced into an encounter with the local cosmological order and likewise the local meanings of human and non-human are the lenses through which conservation is analysed locally. Specifically, we examine the ambiguity of human and non-human encounters and how these relate to the 
conflicting paradigms that underpin the management of Cantanhez National Park on the one hand and the local cosmological order on the other. In particular, we analyse the intriguing multiple role of the chimpanzee as the park's flagship species, as an actor in local claims against the park and in witchcraft accusations.

\section{Methodology and background to the study area}

This paper draws on 13 months of fieldwork carried out in Cantanhez by the first author over a five year period (2009-2013). Interactions with Nalu, Balanta and Fula men and women, as well as youth and elders took place in four villages. Data was gathered through participant observation, informal interactions with local people and through 45 in-depth interviews, held in Kriol, the lingua franca. These interviews sought to gain an in-depth understanding from a range of actors of sensitive issues, especially local narratives about NGOs, the Park and witchcraft. Additionally, we draw on information collected during 92 semi-structured interviews about livelihoods and human-wildlife interactions. Also, comparative fieldwork (including 12 in-depth interviews) was conducted over 8 months in the nearby Boé region (2011-2012) to inform a broader picture of the roles chimpanzees assume in local people's discourses.

Cubucaré today is home to several peoples with a syncretically shared cosmology born of centuries of exchange, war and marriage. Historically, these encounters brought the Islamisation of the Nalu by the Fula and Sussu (Rodrigues 1948), which has contributed to the regional cosmological syncretism of Islam-Animism-Spiritism (see Crowley 1990). This common habitus includes knowledge of restricted social spaces and cosmological niches controlled and delineated by frontiers that may only be accessed by specific ethnic, gender and/or age identities (for e.g. male and female Nalu initiations). Nalu founding lineages are 
known as the descendants of the first settlers of Cubucaré and are recognised as the 'owners of the land'. Having made contracts with the spirits (irã, kl), rights of foundation have passed down to Nalu descendants regarded as responsible for having founded the conceptual, magical, moral and physical determinations of the Nalu homeland (tchon nalu, kl). Consequently, these lineages hold privileged authority in the management of natural resources, judicial processes, and in shaping local morality today. People in Cantanhez have experienced processes of collective, mutual transformation, and endured extended periods of colonial rule, state-centered socialism, economic liberalization and most recently, the endeavours of nature conservation. Given this shared local history in the study area, we use the widely-spoken Guinea-Bissau Kriol lexicon translated into English in what follows below.

Historically, Cantanhez has been an agricultural landscape where small-scale farmers secure their livelihoods through agriculture and trade. Collective work and knowledge transmission are crucial to the practices and technologies involved in swidden agriculture, mangrove rice farming and orchards, crucial for both food security and income generation (Sousa 2014). The economic, social and cosmological components of this social landscape find expression in a peasant rationale of reciprocity between people, and between people and the local spirits. Transgression of reciprocal and re-distributive commitments may translate into different expressions of social criticism and crisis, like sorcery, with a specific type of sorcery here which is based on abnormal affiliations with animals or spirits.

\section{Cosmological entanglement and the interchangeability of bodies}

Almada's $16^{\text {th }}$ century descriptions of the Guinean coast include the idea that the Nalu "have their souls put into animals" such as lions, leopards, or any fierce animal, and that once the animal dies, so does the person (Almada 1594 :69). In Cantanhez today, people believe 
that non-human figures, from insects to chimpanzees, may in fact be something quite different from what they appear at first sight. Local informants intimated that animals may show some physical or behavioural feature that suggests they are not common animals, but something else that has assumed animal form. Local people provided different accounts of these metamorphoses: whilst the bush spirits (irãs $\mathrm{kl}$ ) can present themselves as humans, both the spirits and some people can present themselves as animals. Therefore, neither animals nor people are exclusively bound to their material and determinate existence. One is not trapped in a genetically pre-determined physical existence since one can assume other forms and still maintain ones inner character.

Animals in Cantanhez often mediate communication with the immaterial world and interact with people's lives in highly subjective and symbolic ways incompatible with a nature-culture divide (e.g. birds transporting messages from the spirits, see Sousa 2014). Leopards, pythons and bees are used by spirits as agents for administering justice or as reminders that the spirits and the Nalu founding lineages are the ultimate owners of local natural resources and thus a major authority. An elderly informant explained: "powerful spirits can turn into leopard, crocodile... if a hunter tries to kill these animals... he dies instead". This example illustrates spirits turning into dangerous animals to punish people who consume resources not previously agreed upon in contracts with the immaterial world. Also, in a widely reported local episode, leopards played an important role in accusations of sorcery that led to a geographic and political reorganisation of the chieftaincies as defined by the colonial administration (Sousa 2014). Some local people are also capable of becoming invisible (mina, $\mathrm{kl}$ ), which was said to be common capacity during the independence war in Guinea-Bissau (1963-1974).

Some ethnic groups are described as being able to shape-shift into particular animals. Balanta people, usually living by the mangrove, are known for shape-shifting into crocodiles; 
the Fula, living mainly in a savannah-dominated landscape, into hyenas and barn owls; the Beafada into chimpanzees and hyenas, and the Nalu into chimpanzees and leopards. Chimpanzees are present in considerable densities in the Beafada (Carvalho et al 2013) and Nalu homelands (Sousa et al 2011). A market seller in Bissau said that people can shape-shift into vultures, a very common species in the capital. Therefore, in a given ecology, the physical presence of certain animals, particularly those perceived as fiercesome, provides elements for narratives of shape-shifting, with 'magical animals' making use of their fellow 'natural animals' to exist in witchcraft. Additionally, particular combinations of animals' attributes and behaviours are capable of having several meanings which are understood when interpreted against the subjectivity of particular contexts. The following section explores local narratives of transgressive and ambiguous combinations of animals and people, particularly those involving chimpanzees, which distinguished a "simple animal" (limaria simples, kl) from an "unclean" (sussu) or "shape-shifted" animal (limaria bidadu).

\section{Local expressions of witchcraft and the negotiation of sociability}

Witchcraft has been broadly described as a theory of misfortune that searches for the responsibility behind an undesired event. In Guinea-Bissau, among all the social mechanisms used to construct causal explanations, witchcraft is broadly accessible since one does not need to be recognised as a seer (pauteru, $\mathrm{kl}$ ) to interpret a certain event and participate in the social drama of witchcraft.

As has been widely recognised, witchcraft is connected in complex ways to consumption, accumulation and predation. In Sierra Leone, “chimpanzee cannibalism” was described as a "weapon of the weak", a tool of protest and an "expression of disquiet" against commercial individualism which aimed to break down the collectivist values crucial to rice 
farming (Richards 2000). Both Richards (2000) and Shaw (2001) also link chimpanzee, leopard and crocodile witchcraft to the social memories of the slave trade in Sierra Leone during which people and young children would be preyed upon, kidnapped and sold into slavery. Shaw provides a historical overview of pre-colonial and colonial accusations of cannibalistic witchcraft, which involved rivalries between colonial-era chiefs, merchants and slave raiders. Witchcraft discourses find expression in various socio-political contexts, from slavery to capitalism (Comaroff and Comaroff 1999). Geschiere (2013) discusses the articulation of witchcraft and power in Cameroon in different globalising scenarios, from the village to international networks. A similar reasoning is expressed in the context of international development when the international aid funds are accumulated by "big men", leaving the rural poor feeling that they have been preyed upon (Shaw 2001).

\section{The lexicon of the occult in Cantanhez.}

In southern Guinea-Bissau, belief in witchcraft spans ethnic and religious demarcations. Despite particularistic ways of understanding witchcraft, it is widely recognised and universal to the local cultural understandings. In Kriol, the term futucerundadi, appropriated from the Portuguese feitiçaria, is frequently used in reference to the practice of bad witchcraft (sorcery in Kapferer's definition). A person who has magical capabilities to affect other people's lives through occult forces is understood as dreadful (medunhu): 'Those who want to eat people... those are medunhu'. Here 'sorcery' corresponds specifically to a form of witchcraft understood as used to harm, shoot, kill, or eat, people through the use of magic. A common term in the literature that we consider equivalent to sorcery in our casestudy is 'cannibalism', which denotes the magical or physical consumption and/or annihilation of a human by another human, at times disguised as an animal (Richards 1995; 
Richards 2000; Shaw 1997). The term "eating people" (kume pecadur or nhame pecadur, kl) is a common expression for sorcery in Cubucaré.

Very often sorcery accusations remain gossip and forms of defamation informing the one accused that she/he has become deeply untrustworthy to others. Rarely, people hire wellknown healers to uncover the sorcerer by giving a beverage to the suspect. Brosselard (1889 in Havik 2008:2) described people in Portuguese Guinea carrying out rituals to identify sorcerers with Erythrophleum afzelius (mancone, $\mathrm{kl}$ ), the bark of which is toxic and used to prepare the "red water", which was described by Almada ([1594]1964). In 2010, people in a Balanta village hired an Islamic healer to identify a sorcerer. At the time our Nalu informants challenged the truthfulness of the witch-doctor's judgement and added: "If someone says the another is a sorcerer, either he is a liar or he is a sorcerer as well”. In some Nalu villages, mbantchum (male initiation spirit) is the entity in charge of discovering sorcerers, which are rarely activated (see Sousa 2014). We stress however, that sorcery accusations are in this context at least to be understood as social modes of arguing about power, expropriation and maltreatment.

Witchcraft can operate at different levels of intimacy. It is commonly expressed as aggression towards a kin member (usually a younger descendent: children or nephews/nieces) for personal benefit. Here, the sorcerer is hidden in the most private and intimate realms of the social world - the house. This was reported among the Baga people in Guinea-Conakry (Sarró 2009) and among the Balanta in Guinea-Bissau (Bivar and Temudo 2014). Sarró describes the 'ambivalence of the descent group' as follows: 'Belonging to [a descent group] offers protection and identity to its members, but it can also annihilate them if they do not act in a way conducive to the well-being of the group' (Sarró 2009: 36). People describe sorcerers as a threat to institutions such as kinship, because sorcerers form secret societies which members are permanently indebted to one another: 'if we eat my child today, you're obliged 
to give us your child tomorrow'. Sorcerers are a malevolent representation of mutual help systems in which reciprocal arrangements are established between a restricted circle of consumers of people. Instead of acting for the benefit of kin members, sorcery consumes them for the benefit of sorcerers.

A machination of sorcery in Cantanhez is to eat people via a spell by using non-human skills. Here the body is central to the expression of threat and loss as the sorcerer is empowered through a bodily transformation while the victim is eaten and thus annihilated. In these cases a sorcerer's soul can either abandon his/her body, which 'stays at home but does not move', while the soul enters the body of an animal (entranda na um limaria, $\mathrm{kl}$ ), or the sorcerer's body is able to physically shape-shift (bida, $\mathrm{kl})$ into an animal figure. Another type of sorcery, also perceived as dreadful (medunhu, kl) witchcraft, is 'shooting people by magic' (uaga corte, $\mathrm{kl}$ ). These sorcerers shoot people, they do not eat them - 'it is like being a hunter'. It is learned within the family, but it can be used to harm people beyond the family. In fact, uaga corte configures a more individualistic and transactional approach to sorcery as it can be paid for as a service in which the real sorcerer stays at home and employs another to do their dirty work. To summarise, the central ideas of sorcery as explained by local people in Cantanhez are that sorcery acts at different levels of intimacy, provides illegitimate benefits and implies obligations to a secret society of sorcerers.

\section{Empirical accounts of sorcery in Cantanhez}

In November 2010, in a Fula village in Cantanhez, a young boy was bitten by a snake causing paralysis of his foot. Rumours circulated that an old woman — the child's aunt — was responsible for the attack after having shape-shifted into a snake to bite the boy. This boy had been managing his father's cashew orchard during his father's absence; the injured foot 
forced him to abandon this work. At the time, the boy's father who worked as a teacher, had not received his salary for five months, thus did not have the means to take care of his son's injury. In February 2011, the boy died from an infection reportedly linked to the snake bite. It was said that the old woman killed him because she wanted to take over the family's orchard. In further examples, two cases came to light of Nalu people who were shot using magic (uaga corte): a woman trader and an elder. Both went to the Nalu traditional healer (djambacus, kl) who diagnosed them as having been 'shot through' with a spell. As a trader, the woman regularly travelled to the capital to sell bananas and palm oil. The healer told her she was 'shot' in the foot by someone who envied her and wanted her to stop working. He treated her by apparently removing pieces of plastic from the back of her leg, and by giving her a medicinal cocktail of plants to drink. He did not cut her leg but showed us the pieces of plastic that he claimed to have taken from her leg. She was not charged for the service but was advised to return and pay when she recovered.

The elder's case was more dramatic. He took ill and went to the hospital, but did not recover. His family took him to a healer who said he had been 'shot through' with magic and that was why the hospital medicine could not cure him. The healer allegedly removed three magic bullets from the elder's chest and gave him a mixture of plant medicine that made him vomit blood. This was said to be the blood inside his body as a consequence of having been shot. The healer warned that the old man was already very 'tired' and that anything could happen. He died a few days later.

In the first case, the woman recovered and is still trading products between Cantanhez and Bissau. She had an idea about who had 'shot' her. She revealed that a mechanic from another household in her village was jealous of her success as a trader. He did not participate in the collective work in the fields, perhaps because he had other sources of income. Another case of sorcery accusation referred to a report by an interlocutor of a Nalu healer who said he 
had identified two Fula ex-fighters who had joined the Portuguese side of the Independence war as leaders of the local sorcerers' society. This healer was from a village where people supported the PAIGC (African Party for the Independence of Guinea-Bissau and Cape Verde). One of the Fula men, was also accused of spying during farmers' meetings at which people often criticised the Park. He was suspected of recounting what he had heard to the local NGO staff.

Although the intensity and motives behind accusations vary, such accusations appear to be directed towards those perceived to ask for and/or take too much from others, or keep too much for themselves. In Cantanhez, livelihoods depend on cooperation and mutual help arrangements within and between households that are nevertheless filled with tension. Where there are social obligations to share and reciprocate, asking for too much can be as troubling as accumulating too much, and both fall outside the accepted social calculation of sharing. Giving and receiving are expressed as an inherent norm of the social order; sorcery accusations allow people to argue about and contest the limits of that social norm. In the following section we will show some of the ways in which this fraught, local socio-economic order is crucial to an analysis of the Park's modes of practice.

\section{Portrayals of 'fearless' chimpanzees in a 'greedy' national park}

Cantanhez was recognized as a hunting reserve by the Portuguese colonial administration in 1941. After independence in 1980 it was legally recognized as a protected area (Bouju et al 2001). But it was only in 2008 that it became a National Park and in 2011 the legislation was set out by decree no 14/2011. Previously, in 2002, two local NGOs and an international NGO, local chiefs and the sector administration, had signed an agreement, in the presence of other local people, that approved the internal regulations of the future park 
(Mendes and Serra 2002). These regulations enacted limitations on the use of forests by local people for shifting agriculture and hunting. The model for the park did not follow the exclusionary model of 'parks-without-people', and Cantanhez remained a patchwork landscape of forests, savannas, mangroves and agricultural fields and fallows. Instead, specific forested areas were identified where people were banned from farming, and a policy of fines and fences for controlling access was adopted. On a few occasions more dramatic measures including the burning down of houses to force people to leave a designated wildlife corridor, were also pursued (Sousa 2014, Temudo 2012).

At the time of the first agreement with local authorities, NGOs undertook to financially support mangrove rice farming; provide incentives, field material and courses to community guards; and hold regular meetings (not specified how regular) with the local inhabitants (Mendes and Serra 2002). The details of this initial agreement conformed to the idea of allying nature conservation and development, where biodiversity conservation was expected to bring benefits for local people.

The extent to which it is possible to conserve biodiversity and simultaneously improve livelihoods of those coexisting with wildlife is debated extensively within the literature (Adams et al 2004; Novelli and Scarth 2007). The attempt to ally conservation and development has been described as a difficult marriage (Hill 2002; West and Carrier 2004) since often the benefits from tourism in protected areas do not reach local people (see Novelli and Scarth 2007). Similarly, several people in Cantanhez commented on the park and NGO's failure to meet the agreed-upon commitments, and suggested there had been minimal support for mangrove rice farming, no salaries provided for guards, and barely any meetings held to discuss the management of the park. Between 2007 and 2013, local people requested several times for meetings with the heads of conservation organisations, but without success. In 2007 there was a strike preventing tourists from entering local forests and local people removed the 
signs indicating the names of the different forests. Subsequently chieftains were criticised for aligning themselves with conservation projects and 'forgetting' local people (see Temudo 2012 for conflicts with the Park in 1990-2000s).

Within the park's management framework, the chimpanzee was described as 'one of the most important species' in Cantanhez and a potential promoter of ecotourism (Bouju et al 2001). In early 2000s a tourism project was launched by a local NGO and the chimpanzee became firmly associated with the park, both for tourists and for local people. By 2007 'chimpanzee tourism' had already raised considerable expectations among local people regarding the economic advantages that would supposedly flow into the area (Sousa et al 2014). In 2010 and 2011, tour guides were paid by tourists to visit the forests and observe chimpanzees. Other local people regarded this tourism venture as a benefit that should be shared because the conservation of forests and chimpanzees is a burden on everyone. A young Nalu man argued:

The park could be a good thing because if my friend becomes a park employee and he receives a salary there, I will benefit because we all eat together... Therefore I cannot say that I did not 'eat' the park's money. When I eat rice, I am 'eating' it. If he buys tea, I will 'drink' the park's money. If I do not have money I can ask him, and he can lend it to me as a friend. Then, I cannot say I did not eat it.

However, in discussions that go beyond the local contexts where perceived benefits are negotiated among local people, critical views about nature conservation shift towards larger institutions. In 2011, several farmers claimed a share and a formal say in the management of the funds from the NGO-managed hotel where tourists are hosted. A farmer indicated that allegedly, from 23rd October 2010 to 4th January 2011, 1.260.000 XOF $(\approx 2.048$ USD) was transferred to the hotel by visiting tourists. By comparison, in 2010-2012, the daily rate for agricultural labour locally was $1,004 \pm 370 \mathrm{XOF} /$ day $(\approx 0.28 \pm 0.09 \mathrm{USD} /$ hour $)$ (Sousa 2014). People claimed that money is generated by the park, and therefore by the forests and wildlife that people have preserved. In a local meeting in 2012 farmers decided to 
go to the regional administration to claim "their rights to development" because they felt the NGO had done nothing to respond to their claims. The following quote from a farmer illustrates a widely shared sense of what the park meant: 'We gave them the forests. What did they give us? Nothing! Don't you ever tell me about preserving forests!' (2011). Another man argued, 'They put us side by side with animals, as if we do not know anything about anything. (...) They denied us the forest. We will deny elections and population census campaigns'. Here the discontent registers as a protest against the state itself, which is perceived to support nature conservation.

In this small-scale ecotourism initiative forests and chimpanzees have been conceptualised as resources for the production and consumption of tourism and conservationrelated benefits (Novelli and Scarth 2007). Indeed, for actors in Cantanhez, ecotourism added another component to the local representations of nature. Chimpanzees were now regarded as an attractor of international interest and a means of generating valuable income.

Consequently, this has been integrated into local political narratives where chimpanzees became a bargaining chip in claims for crop loss compensation requested from the state, NGOs, and from other local people thought to receive benefits from conservation ( Sousa 2014). All individuals understood to benefit from wild animals are taken by the wider local population as being responsible for them. A local tour guide reports: "The community accosts us because of the animals. They say 'This year we do not have anything to eat because the chimpanzee damaged our cashew"'. The local critical assertions about chimpanzees exist at different levels and include reports of crop loss, interpretations about people-chimpanzee encounters and symbolic representations of confinement and abandonment perceived to arise from nature conservation. Moreover, several people reported that chimpanzees had increased in number and changed their behaviour with the park's creation: 'now the chimpanzee is shameless because he is protected; now he is famous and fearless'. 
It is said that the chimpanzee was once a very lazy smith condemned by God to live in the forest with a non-human appearance: 'We do not eat chimpanzee. They were smiths in the past but were transformed into chimpanzees'. There are in fact several studies that report a peaceful coexistence between chimpanzees and people in southern Guinea-Bissau. Costa et al (2013: 6) report that '[in other areas] chimpanzees... are thought to attack women and children', but they provide no evidence for anything similar in Cantanhez. Karibuhoye (2004:75) reported that in Cantanhez chimpanzees are tolerated because they are not considered a significant cause of crop damage (Hockings and Sousa 2012). However, in spite of the considerations above, losses caused by chimpanzees in banana, orange and cashew plantations can reportedly lead to problems between farmers and chimpanzees (Sousa 2014). In fact, local symbolic understandings of chimpanzees have multiplied and evolved with nature conservation programmes.

A well-known rap singer from Quinara region, Masta Tito, mentions the chimpanzee in a song from the 2000s: 'Ugly government rulers look just like chimpanzees. The rulers of Guinea are like a hyena's intestine' (Governantes feo e parce son dari. Governantes di Guine e tipo tripa di lubu, kl). Physical features of the chimpanzee and hyena are used to critically evaluate and disparage the political elite of Guinea-Bissau. Both verses refer to physical characteristics understood in terms of social discontent. Hyenas are also considered fiercesome, and unsurprisingly both animals are implicated in sorcery discourses.

In Cantanhez, encounters between local people and chimpanzees may occur in any section of the bush-village continuum, however, harmful behaviour by chimpanzees towards humans is rarely reported. During five years, two exceptions to this occurred in the north of Cantanhez. One was in December 2009, when a man lost his finger to a chimpanzee bite. The man never returned to the village but several people recounted the episode: he tried to defend his oranges and shot a female chimpanzee. At that point, a male chimpanzee charged, took the 
man's gun, beat him up and bit off his finger. The man had to be hospitalized. This episode was reported as a chimpanzee's retaliation to harassment. Another incident took place in 2011 when a chimpanzee attacked a hunter who was known for his abilities to call wildlife. The man had to be taken to the hospital in Quebo. This incident was also explained as the result of a man attracting and teasing a chimpanzee.

Chimpanzee attacks are sometimes understood as instances of humans shape-shifting into chimpanzees (bida dari, kl). In Cantanhez, reports of chimpanzee attacks on people increase when 'shape-shifted chimpanzees' (dari bidadu, kl) are discussed. While 'clean' or bush chimpanzees are perceived to be harmless, chimpanzees that do not run away from people are suspected of being 'unclean' (dari ka limpu). Informants reported that chimpanzees that attack people without being harassed are not 'real' chimpanzees: 'They are people who shape-shift into chimpanzees to commit crimes'. Below are five short extracts from interviewees about attacks by unclean chimpanzees.

\section{Report in 2011 (Cacini, Tombali):}

During the colonial period, women used to go to collect oil-palm kernels in oilpalm groves. (...) A woman had her grandchild on her back. A chimpanzee came and took the child, despite the grandmother attempting to fight the chimpanzee off, [it] bit him [the child] all over his body and took out one testicle. (...) They took him to the hospital, but he died.

\section{Report from late 2011 (Tombali di Bas):}

This last month a chimpanzee killed a person in Tombali, during the groundnut harvest. A shape-shifted chimpanzee went to fight with a man (...). When the chimpanzee and the man met, the man got up and asked the chimpanzee where 
he was going. The chimpanzee replied: 'I came to fight with you', and (...) went over to him, beat him until he was cold, [and] it killed the man. People found the body, but they did not see the chimpanzee, only signs of its having been there.

\section{Report from 2011 (Cantanhez, Tombali):}

I was cooking in the backyard... Once in a while I would see a chimpanzee seated on the balcony of the house next to ours, which is part of a compound belonging to my family. At that time, I already thought that it was not 'clean'. A few days later, I was looking after the chickens and a chimpanzee was hiding behind the goats. The goats moved away and the chimpanzee grabbed my leg. People came to chase it away and nothing happened in the end, but I was scared. It was a not a clean chimpanzee, it was futucerundadi [sorcery].

\section{Report from 2011 (Cantanhez, Tombali):}

I was going from one village to the other and a chimpanzee, a big one, grabbed my hand and talked to me. I knew who shape-shifted into a chimpanzee. I told her I would not eat people as she wanted.

\section{Report about the 1990s (northern Boé):}

We do not know what got the boy. (...) We looked for him for three days. He was with other children, they were looking for fole [fruits of Landolphia sp]. The others said that something like a chimpanzee appeared, something black, but they do not know for sure what type of thing it was. The authorities came, 'people that know' [magical abilities] were asked and they discovered that the 
boy's mother knew about what had happened. People decided that since his mother knew what killed her son, they could not do anything, since the law does not say that the mother should be killed. His mother ended up leaving and moved to another village, away from the region.

Recently (in 2016) there have been reports of chimpanzee attacks on children in Quinara (Guinea-Bissau) in which children were severely harmed with feet, hands and face injured and a few amputated toes. In an interview with one victim and his friend, who was present during the attack, the chimpanzee was reported as not a "clean chimpanzee" but a shape-shifted chimpanzee. From Cantanhez in the Tombali region to Empada in Quinara region (a linear distance of approximately $40 \mathrm{~km}$ ) or to the Boé in Gabu region (a distance of approximately $140 \mathrm{~km}$ ), there is a regional consensus regarding the symbolic meaning behind 'unclean' chimpanzees. In the literature, there are reports of chimpanzees acting aggressively towards people, for example chimpanzees killing children and babies in Sierra Leone (Richards 2000), chasing people in Uganda (McLennan and Hill 2010), injuring children in Guinea-Conakry (Hockings et al 2010), and carrying out lethal attacks on children in Uganda (McLennan and Hill 2013). In southern Guinea-Bissau, people said that if it is a clean chimpanzee 'it goes away when it sees you, it will not attack you just like that; if it does, it is because it is not clean $($ limpu, $\mathrm{kl})$ '. In the descriptions above, the identity of the aggressor was not mentioned but the idea that the aggressor belonged to the victim's family was often suggested. Significantly, the aggressor is not perceived of as a chimpanzee but as a person who is trying to harm his/her kin. As such, these incidents are not portrayed as something that would interest chimpanzee conservation; they are understood as intimate, domestic problems and are probably under reported to external nature conservation authorities. 
The expression and coordinates of sorcery may shift to articulate with the spheres in which it manifests itself. The anecdote below refers to an ambiguous interpretation of a chimpanzee attack. In 2010, all the neighbours of Aua [a pseudonym] were certain that she had been attacked by a shape-shifted chimpanzee while collecting oil-palm bunches in the forest. Aua was grabbed and had her back scratched by a chimpanzee before a man chased the animal away. This unprovoked attack could potentially be understood as sorcery. However, Aua portrayed it as an attack of a bush chimpanzee and held the head of the NGO responsible for the incident. When asked whether it was a clean chimpanzee or a bush chimpanzee, Aua said she was unsure and added: 'I will send a message to Bla [pseudonym, the NGO's director] to say that his chimpanzees are harming people'. Thus, an unprovoked attack by a chimpanzee was perceived as an outcome of sorcery by neighbours, but it was represented by Aua as an attack by a bush chimpanzee. Nevertheless, while the behaviour is naturalised, it does not lose its social meaning as it serves different purposes for different actors.

Tourists, local tour guides, conservation NGOs, community guards, and researchers associated with chimpanzee conservation were all called 'chimpanzee people' by local people. 'Chimpanzee people' are urban and rural, black and white, from different ethnic groups, Bissau-Guineans, locals or foreigners. Sometimes local people use the term 'bo parentis' (kl, your family) to name people involved in chimpanzee conservation and refer to chimpanzees as their children (bo fidjus, kl), those whom one aims to protect. Conservation stakeholders are perceived to behave as a member of a chimpanzee's kin/group as they benefit from and defend chimpanzees at the expense of other people subjected to the national park legislation.

The manifestations of sorcery we registered in Cantanhez are principally addressed towards those perceived by others to avoid or renege on reciprocal arrangements or social obligations of sharing. There was already tension among local people regarding the sharing of perceived benefits that accompany the expansion of the conservation initiative. A local tour 
guide says: 'Each day we have fights with people of our own community. (...) If I say, "Do not harass chimpanzees", people say, "Give me [a share]". They fight against you, and we are afraid of that'. Although sorcery discourses do not affect conservation stakeholders who do not live locally, reference to them as chimpanzee kin implies that their actions support chimpanzee conservation at a cost to fellow humans. Chimpanzees are involved in two parallel accusation discourses, one is played out in intimate spheres of local sociality where sorcerers harm their kin to benefit their secret alliances, and the other addresses a wider audience perceived to benefit from chimpanzees, which are being protected at the expense of local people.

\section{Concluding remarks}

In Cantanhez a distinction is made between bush and village which does not correspond to a binary nature-culture opposition, rather it distinguishes an environment with multiple and unexpected natural-social elements (bush) from another with more familiar natural-social elements (village). As described by Descola (1994:324), this bush-village distinction is a continuum in which some combinations are considered worrisome and out-ofplace. Examples include animal figures having a village-based agenda and being understood as 'unclean'. In this ontological view of nature, an 'unclean' chimpanzee is embodied by a person that sees other people as prey. In Cantanhez, animals are not naturally violent, but are instead indicative of an intimate crisis in which a sorcerer and a member of a secret society prey upon kin members. What we have argued here is that there is a distinct possibility that chimpanzee attacks on people in Cantanhez have historically been kept quiet because they are widely regarded as a people-people matter rather than as 'human-animal conflict'. 
As Descola (1996:90) argues, 'reciprocity and predation constitute dominant schemes permeating the ethos of a culture'. Close to the encounter of the forces of reciprocity and predation, witchcraft thus appears to be intimately related to people's views of production and consumption (Moore and Sanders 2001). Today it is the relationship between local people and conservation institutions in Cantanhez that is troubled and ambiguous, where expectations of revenues (Sousa et al 2014), protests and distrust coexist with benefits reaching only a few and the costs of conservation being inflicted upon the many (Sousa 2014). In the end, nature conservation is about the conservation of wilderness and ecological resources, but it is no less about meaning, production, predation and distribution, and is therefore also connected to the reasoning that configures sorcery.

Whether understood as punished smiths, crop foragers, the embodiment of sorcerers, or conservationists' kin, chimpanzees are unavoidably protagonists in the human social world. As Descola (2012:447) argues it is the "principles according to which socio-cosmological collectives are organised" that are crucial for understanding the relationships people establish among themselves and with other creatures. In the context of Cubucaré, this is based on social forces that push for the sharing of resources, costs and benefits among human and non-human actors. Simmons (1980) has suggested that even when grievances originate from outside they can only be negotiated internally. Local people involved in chimpanzee conservation and perceived to receive benefits from it are pushed by others to share the rewards. It seems clear that the future meanings and characterisations of chimpanzees in local narratives, either in their clean or unclean forms, depends on local people recognising a place for themselves within the extant model of nature conservation. At the very least, it must also cultivate greater space for participative governance. But this may not ultimately be enough: The ontological turn would seem to have political implications for the legitimacy of nature conservation to defend and argue for particular formulations of nature and their capacity to extend to the rest 
of the word. The recognition of different ontologies suggests that there is not 'nature' on one hand and the 'representations of nature' on the other. Indeed, there is not one nature to which specific social groups attribute meanings, rather, there is an intermingling of human, nonhuman creatures, objects and the relations they establish (Descola 2008, 2013). Nature conservation initiatives, based on a fabricated universalism of international treaties and national legislation promoting the conservation of bio-diversity, are centrally implicated in these contests. In Cantanhez, narratives about nature and specifically chimpanzees are connected both to unease within the intimate space of the house and to distrust of the global discourse of nature conservation. In Cantanhez, misunderstandings and conflict are predicated upon economic and power asymmetries, on different ontological perspectives about humanchimpanzees relations and on different ways of 'being (with) chimpanzees'.

\section{Literature}

Adams, W. Hulme D. 2001 If community conservation is the answer in Africa, what is the question? Oryx 35(3):193-200.

Adams, W. Aveling R. Brockington D. et al. 2004. Biodiversity conservation and the eradication of poverty. Science 306(5699):1146-1149.

Almada, A. 1594. Tratado breve dos rios de Guiné do Cabo-Verde. Porto: L.I.A.M.

Bivar, M. Temudo M. 2014. Rice, cows and envy: agriculture and change among young rice producers in Guinea-Bissau. Future Agricultures.17pp. 
Bouju, S. Catry P. Cordeiro P. 2001. Les aires protégées de Guinée-Bissau. Propositions pour une stratégie nationale 2001-2005. Bissau: IUCN.

Brockington, D. Igoe J. 2006. Eviction for conservation: a global overview. Conservation and Society $4(3): 424$

Carvalho, J. Marques T. Vicente L. 2013. Population status of Pan Troglodytes Verus in Lagoas de Cufada Natural Park, Guinea-Bissau. PLOS ONE 8(8):e71527.

Comaroff, J. Comaroff J. 1999. Occult economies and the violence of abstraction: notes from the South African postcolony. American Ethnologist 26(2):279-303.

Costa, S. Casanova C, Lee P. 2013. The good, the bad and the ugly: perceptions of wildlife in Tombali (Guinea-Bissau, West Africa). Journal of Primatology 2(1):1-7.

Descola, P. 1994. In the society of nature. A native ecology in Amazonia. Cambridge: University of Cambridge.

Descola, P. 1996. Constructing natures, symbolic ecology and social practice. In Nature and society: anthropological perspectives. P. Descola. G. Palsson, (eds.), London: Routledge.

Descola P. 2008 Who owns nature ? Books and ideas. ISSN : 2105-3030. http://www.booksandideas.net/Who-owns-nature.html, accessed December 18, 2016. 
Descola P. 2012. Beyond nature and culture forms of attachment. Journal of Ethnographic Theory 2(1):447-471.

Descola P. 2014. Modes of being and forms of predication. Journal of Ethnographic Theory 4(1):271:280.

Geschiere, P. 2013. Witchcraft, intimacy and trust. Africa in comparison. London: The University of Chicago Press.

Hill, C. 2002. Primate conservation and local communities: ethical issues and debates. American Anthropologist 104(4):1184-1194.

Hockings, K., Sousa C. 2012. Differential utilization of cashew-a low-conflict crop-by sympatric humans and chimpanzees. Oryx 46(03):375-381.

Hockings, K., Yamakoshi G, Kabasawa A, Matsuzawa T. 2010. Attacks on local persons by chimpanzees in Bossou, Republic of Guinea: long-term perspectives. American Journal of Primatology 72(10):887-896.

Kapferer, B. 2002. Outside all reason: magic, sorcery and epistemology in Anthropology. Social Analysis 46(3):1-30.

Karibuhoye, C. 2004 Mammal conservation status and prospects for community-based wildlife management in coastal Guinea-Bissau, West Africa. PhD, Georg-August-Universität zu Göttingen. 
McLennan, M. , Hill C. 2010. Chimpanzee responses to researchers in a disturbed forest-farm mosaic at Bulindi, Western Uganda. American Journal of Primatology 72(10):907-918.

McLennan, M. Hill C. 2013. Ethical issues in the study and conservation of an African great ape in an unprotected, human-dominated landscape in Western Uganda. In Ethics in the field: contemporary challenges. J. MacClancy. A. Fuentes, (eds.), New York: Berghahn Books.

Mendes, N. Serra A. 2002. As medidas de Iemberém sobre a co-gestão das 14 matas de Cantanhez. Iemberém.

Moore, H. Sanders, T. 2001. An introduction. In magical interpretations, material realities: modernity, witchcraft and the occult in postcolonial Africa. H. Moore T. Sanders, (eds.), 127. Psychology Press.

Neumann, R. 2002. The postwar conservation boom in British Colonial Africa. Environmental History 7(1):22-47.

Novelli, M. Scarth A. 2007. Tourism in protected areas: integrating conservation and community development in Liwonde National Park (Malawi). Tourism and Hospitality Planning \& Development 4(1):47-73.

Richards, P. 1995. Local understandings of primates and evolution: some Mende beliefs concerning chimpanzees. In Ape, man, apeman: changing views since 1600. R Corbey. B. Theunissen, (eds.) 265-273. Leiden University. 
Richards, P. 1996. Chimpanzees, diamonds and war. The discourses of global environmental change and local violoence on the Liberia-Sierra Leone border. In The future of anthropological knowledge. H. Moore. (eds), 140-155. London: Routledge.

Richards, P. 2000. Chimpanzees as political animals in Sierra Leone. In Natural enemies: people-wildlife conflicts in anthropological perspective. J. Knight, (eds.), 78-103. Oxon: European Association of Social Anthropologists.

Rodrigues, M. 1948. Os maometanos no futuro da Guiné Portuguesa. Boletim Cultural da Guiné Portuguesa III(9):219-231.

Roe, D. 2008 The origins and evolution of the conservation-poverty debate: a review of key literature, events and policy processes. Oryx 42(4):491-503.

Sarró, R. 2009. The politics of religious change on the Upper Guinea Coast. Iconoclasm done and undone. Edimburgh University Press.

Schmidt-Soltau, K. 2005. A roadmap to sustainability: learning from the mistakes of conservation and development induced involuntary displacements in Central Africa.

Shaw, R. 1997. The production of witchcraft/witchcraft as production: memory, modernity, and the slave trade in Sierra Leone. American Ethnologist 24(4):856-876. 
Shaw, R. 2001. Cannibal transformations. Colonialism and commodification in the Sierra Leone hinterland. In Magical interpretations, material realities: modernity, witchcraft and the occult in postcolonial Africa. H. Moore. T. Sanders, (eds.), 50-70. Psychology Press.

Simmons, W. 1980 Powerlessness, exploitation and the soul-eating witch: an analysis of Badyaranke witchcraft. American Ethnologist 7(3):447-465.

Sousa, J. 2014 Shape-shifting nature in a contested landscape of southern Guinea-Bissau. $\mathrm{PhD}$, Oxford Brookes University.

Sousa, J. Barata A. Sousa C. Casanova C. Vicente L. 2011. Chimpanzee oil-palm use in southern Cantanhez National Park, Guinea-Bissau. American Journal of Primatology 73(5):485-497.

Sousa, J. Vicente L. Gippoliti S. Casanova C. Sousa C. 2014. Local knowledge and perceptions of chimpanzees in Cantanhez National Park, Guinea-Bissau. American Journal of Primatology 76(2):122-134.

Temudo, M. 2009. A narrativa da degradação ambiental no sul da Guiné-Bissau: uma desconstrução etnográfica. Etnográfica. 13(2):237-264.

Temudo, M. 2012. "The white men bought the forests": conservation and contestation in Guinea-Bissau, Western Africa. Conservation and Society 10(4):354-366. 
West, P. Carrier J. 2004. Ecotourism and authenticity: getting away from it all? Current Anthropology 45(4):483-498. 